\title{
PENGEMBANGAN USAHA KRUPUK SUSU IBU-IBU PKK DESA JABUNG KECAMATAN JABUNG KABUPATEN MALANG
}

\author{
Dyah Triwahyuningtyas, Farida Nur Kumala \\ Universitas Kanjuruhan Malang \\ dyahtriwahyu@unikama.ac.id, faridankumala@yahoo.com
}

\begin{abstract}
Abstrak
Masyarakat dusun Umpak dan Mindi sebelumnya telah diberikan pelatihan pembuatan krupuk susu. Hasil dari pelatihan tersebut adalah terciptanya industri rumah tangga atau UKM pembuatan krupuk susu. Hasil dari UKM ini cukup digemari warga sekitar. Namun untuk pemasaran dan pengembangan usaha kearah yang lebih luas belum dapat dijalankan, mengingat usaha ini belum memiliki ijin dan manajemen yang tepat selama proses produksi hingga pemasaran. Menanggapi masalah tersebut perlu ditawarkan suatu ipteks tentang cara pengembangan usaha krupuk susu yang bertujuan untuk mengembangkan UKM krupuk susu melalui proses pelatihan manajemen usaha krupuk susu dan pembuatan perijinan ke dinas kesehatan setempat. Program pelatihan ini terdiri dari tiga sesi yaitu pelatihan manajemen usaha krupuk susu, perijinan PIRT ke dinkes dan evaluasi program. Adapun luaran pada program pelatihan ini adalah terciptanya usaha krupuk susu yang berkembang di beberapa tempat salah satunya adalah pusat oleh - oleh. Hasil dari program pengabdian ini sebagai berikut: 1). Usaha krupuk susu telah memiliki manajemen yang lebih baik selama proses produksi hingga pemasaran yang dilengkapi dengan administrasi untuk menunjang kegiatan UKM, 2). Telah mendapatkan nomor ijin dagang rumah tangga (PIRT) setelah dilalui melalui beberapa tahapan. 3). Kegiatan pemasaran produk melalui online dan juga merambah sektor pariwisata (toko oleh - oleh).
\end{abstract}

Kata kunci: Manejemen, PIRT, Krupuk susu.

\begin{abstract}
Pedestals and Mindi village communities had previously been given training on making crackers milk. The results of the training was the creation of a domestic industry or SME manufacturing of milk crackers. The results of these SMEs are quite popular people around. But for marketing and business development towards more extensive can not be executed, considering that this business does not have permission and proper management during the process of production to marketing. Responding to these problems need to be offered a science and technology on how to milk chips business development aimed at developing SMEs crackers milk through milk chips business management training and manufacturing licenses to the local health department. The training program consists of three sessions: milk chips business management training, licensing PIRT to dinkes and program evaluation. The outcome of the training program is the creation of a milk chips business is growing in some places one of which is the center of the - by. The results of this dedication program as follows: 1). Milk chips business has to have a better management during the production process to marketing that comes with the administration to support the activities of SMEs, 2). It has been getting a trade license number of households (PIRT) after passed through several stages. 3). Products through online marketing activities and also penetrated the tourism sector (the store by - by).
\end{abstract}

Keywords: manejemen, PIRT, Krupuk milk.

\section{PENDAHULUAN}

Wilayah dusun Umpak bersebelahan dengan dusun Mindi yang merupakan wilayah yang berada di Kecamaan Jabung Malang. Perekonomian penduduk di wilayah Kecamatan Jabung hampir $90 \%$ adalah sebelumnya bermata pencaharian sebagai petani, baik petani kebun maupun petani ternak, akan tetapi sebagian besar petani perkebunan juga mempunyai atau memelihara ternak di rumah masing-masing.

Ternak yang diusahakan oleh penduduk di Kecamatan Jabung ini sebagian besar merupakan peternakan sapi perah. Kebanyakan masyarakat hanya menjual hasil produknya secara mentah sehingga keuntungan yang didapatkan oleh peternak sangat sedikit. Untuk 
menaggulangi hal tersebut telah dilaksanakan ipteks bagi masyarakat yaitu pelatihan pembuatan, pengemasan dan pemasaran krupuk susu.

Krupuk merupakan krupuk adalah makanan ringan yang pada umumnya dibuat dari adonan tepung tapioka dicampur bahan perasa seperti udang atau ikan. Kerupuk dibuat dengan mengukus adonan sampai matang, kemudian dipotong tipistipis, dikeringkan di bawah sinar matahari sampai kering dan digoreng dengan minyak goreng yang banyak. Makanan ini populer di kalangan masyarakat Indonesia sebagai lauk hidangan serta sebagai jenis lomba makan utama pada peringatan Hari Kemerdekaan Indonesia. Kerupuk tidak selalu berbahan dasar tepung tapioka, tetapi lebih kepada 3 proses persiapan. Pembuatan, pengeringan, dan pemasakan (bisa digoreng dengan minyak ato pasir, atau dibakar).

Jenis-jenis kerupuk yang paling umum dijumpai di Indonesia adalah Kerupuk udang dan kerupuk ikan. Harga Kerupuk relatif murah seperti kerupuk Sagu atau kerupuk yang hanya dibuat dari adonan sagu dicampur garam, bahan pewarna makanan, dan vetsin. Kerupuk biasanya dijual di dalam kemasan yang belum digoreng. Kerupuk kulit dan Kerupuk ikan dari jenis yang sulit mengembang ketika digoreng biasanya dijual dalam bentuk sudah digoreng karena krupuk perlu digoreng sebanyak dua kali. Kerupuk perlu digoreng lebih dulu dengan minyak goreng bersuhu rendah sebelum dipindahkan ke dalam wajan berisi minyak goreng panas.

Susu adalah salah satu jenis minuman yang bermanfaat besar bagi kesehatan. Susu merupakan bahan konsumsi yang wajib diberikan kepada bayi untuk menunjang pertumbuhan dan perkembangannya. Kandungan nutrisi dan rasanya yang manis, membuat produk susu disukai banyak orang, termasuk orang dewasa. Susu umumnya lebih banyak digunakan untuk bahan produk makanan atau minuman yang bercita rasa manis, seperti es krim, kue bolu, dan pastel.

Berdasarkan hasil kegiatan tersebut telah tercipta atau terbentuk usaha krupuk susu yang mampu memproduksi krupuk susu dalam jumlah besar. Hasil produk usaha ini cukup digemari oleh masyarakat sekitar, hal ini ditunjukkan setiap kali produksi pembuatan krupuk susu baik mentah ataupun matang dalam waktu dua hari atau tiga hari telah habis terjual.

Keadaan seperti ini disebabkan harga jual yang murah dari produsen yakni Rp. 5000/ ons. Namun, disisi produsen harga yang sangat murah ini kurang berimbang dengan tenaga yang dikeluarkan. Selain itu dalam usaha krupuk susu ini, mitra belum memiliki hak dan kewajiban (jobdesk) yang jelas untuk bekerja. Sistem yang digunakan masih menggunakan sistem gotong royong, sehingga pembagian hasil dan administrasi tidak jelas.

Masalah lain adalah untuk mengembangkan usaha krupuk susu ini diperlukan pemasaran yang lebih luas dan dijual dengan nilai yang lebih tinggi. Misalnya penjualan ke minimart lokal, toko - toko atau pusat oleh - oleh. Namun, untuk dapat memasarkan produk ketempat tersebut diperlukan perijinan ke dinas kesehatan terkait untuk mendapatkan ijin dagang rumah tangga (PIRT).

Menanggapi masalah tersebut diperlukan beberapa solusi alternatif untuk mengatasi permasalahan yang terjadi, diantaranya manajemen pengelolaan usaha krupuk susu dan perijinan pembuatan ijin dagang rumah tangga (PIRT) ke dinkes setempat.

Menurut Griffin (2004) Manajemen diartikan sebagai proses perencanaan / planning, pengorganisasian, pengkoordinasisasian, serta pengontrolan setiap sumber daya yang ada guna mencapai tujuan ataupun goals yang telah ditentukan dengan efektif dan efisien. Efektif berarti tujuan dapat dicapai sesuai dengan rencana yang ada, dan efisien berarti dilaksanakan dengan benar dan terorganisis yang sesuai dengan jadwal yang telah ditentukan. Stoner "IImu Manajemen merupakan proses dalam membuat suatu perencanaan, pengorganisasian, pengendalian serta memimpin berbagai usaha dari anggota organisasi dan juga menggunakan semua sumber daya yang dimiliki untuk mencapai tujuan yang ditetapkan.

Ditambahkan menurut Fayol (1958), Manajemen memiliki fungsi: PLANNING - 
Perencanaan tujuan perusahaan dan bagaimana strategi untuk mencapai tujuan tersebut dengan sumber daya yang tersedia. Perencanaan terbagi menjadi perencanaan strategi dan perencanaan operasional. Organizing Pengorganisasian atau singkronisasi sumber daya manusia, sumber daya alam, sumber daya fisik, dan sumber daya modal dalam rangka mencapai tujuan perusahaan. Commanding - Fungsi commanding sama dengan mengarahkan (actuating). Commanding dilakukan dengan memberikan arahan kepada karyawan agar dapat menunaikan tugas mereka masingmasing. Selain itu, commanding dilakukan agar tugas dapat dilaksanakan dengan baik dan sesuai pada tujuan yang telah ditetapkan semula. Coordinating - Untuk melakukan berbagai kegiatan agar tidak terjadi kekacauan, percekcokan, kekosongan kegiatan, dengan jalan menghubung-hubungkan, menyatupadukan dan menyelaraskan pekerjaan-pekerjaan bawahan sehingga terdapat kerjasama yang terarah dalam usaha mencapai tujuan bersama atau tujuan organisasi. Controlling - Controlling atau pengendalian atau pengawasan adalah suatu kegiatan untuk memantau, membuktikan, dan memastikan seluruh kegiatan yang telah direncanakan, diorganisasikan, diperintahkan, dan dikondisikan sebelumnya dapat berjalan sesuai target atau tujuan tertentu

Berdasarkan hal tersebut melalui menajemen diharapkan suatu usaha dapat lebih tertata dan memiliki tujuan yang jelas sehingga sumberdaya manusia maupun bahan dapat dimanfaatkan secara tepat untuk mendapatkan keuntungan maksimal.

Program pengabdian ini terdiri dari tiga tahapan yaitu tahapan pelatihan manajemen kegiatan usaha kecil, pembuatan perijinan usaha dagang rumah tangga dan evaluasi. Diharapkan melalui program ini, dapat mengembangkan usaha krupuk susu menjadi usaha yang memiliki manajemen tepat guna dan mampu menjadi usaha yang lebih besar karena dapat memasarkan pada area yang lebih luas. Selain itu diharapkan kesejahteraan mitra (kelompok usaha) menjadi lebih baik.
Adapun beberapa dampak jangka panjang kegiatan yang diharapkan muncul adalah: (1) terciptanya manajemen usaha bagi usaha krupuk susu (2) mendapatkan nomor ijin dagang rumah tangga (PIRT), (3) berkembangnya usaha krupuk susu dengan pemasaran mencapai area yang lebih luas.

\section{METODE}

$\begin{array}{rrrr}\text { Beberapa } & \text { solusi } & \text { yang akan } \\ \text { dilaksanakan } & \text { untuk } & \text { mengatasi }\end{array}$ permasalahan mitra adalah sebagai berikut:

\section{a. Pelatihan manajemen usaha kecil}

Pada pelatihan ini, mitra dilatihkan cara mengatur usaha yang dijalankan. Aspek yang dikelola terdiri dari aspek administrasi, sumber daya bahan dan pengelolaan sumber daya manusia. Pelatihan ini berlangsung selama satu hari yang diikuti oleh dua mitra yang mengembangkan usaha krupuk susu.

\section{b. Pembuatan ijin dagang rumah tangga PIRT}

Proses pembuatan krupuk susu diawali dengan pengajuan ijin ke dinkes setempat, dilanjutkan pelatihan yang diikuti oleh mitra selama 2 hari. Tahapan terakhir adalaha kunjungan lapangan ke tempat usaha. Kunjungan ini bertujuan mengetahui keadaan dan kehigienisan proses dan produk. Jika telah memenuhi persayaratan yang dikeluarkan oleh dinkes, maka usaha tersebut berhak mendapatkan nomer ijin dagang rumah tangga (PIRT).

\section{c. Evaluasi program.}

Kegiatan evaluasi program dilaksanakan diakhir kegiatan untuk mengetahui efvektifitas program meliputi observasi pemasaran dan manajemen yang telah dilakukan oleh mitra. namun, dengan daya kreatifitas kuliner, kita juga dapat memanfaatkan bahan susu untuk produk olahan makanan yang bercita rasa nonsweetness. Salah satu yang akan disajikan dalam blog kerjausaha.com ini adalah pembuatan kerupuk susu. Produk olahan susu yang berupa kerupuk gurih nan renyah merupakan bahan makanan yang cukup unik dan menarik sehingga jika dijadikan sebagai ladang usaha, berpeluang menghasilkan profit yang oke. 
Bagaimanakah caranya memulai usaha membuat kerupuk susu

Persiapan Alat dan Bahan:

Bahan-bahan yang diperlukan antara lain: 2 liter Susu pecah atau disebut juga susu segar atau susu mentah, $1 \mathrm{~kg}$ tepung terigu, $1 \mathrm{~kg}$ tepung tapioka, 5 butir telur ayam, $10 \mathrm{gr}$ baking powder, Bumbu sesuai selera, terdiri dari ulekan bawang putih, kemiri, dan garam.

Cara memproduksi kerupuk susu: Seluruh bahan dicampur dalam satu wadah dan diaduk hingga rata dan tidak lengket. Setelah proses pembuatan bahan mentah adonan kerupuk tersebut selesai, langkah berikutnya adalah mengukus selama 1-2 jam. Kemudian diamkan adonan yang telah matang tersebut selama semalam untuk menjadikannya lebih padat. Langkah selanjutnya adalah memipihkan adodan menjadi tipis-tipis dan dipotong sesuai selera, kemudian dijemur di bawah terik matahari hingga kering.

Goreng kerupuk mentah tersebut dengan api sedang, kemudian setelah ditiriskan siap dibungkus dengan plastik kemasan agar tetap renyah dan siap dipasarkan. Demikian sekilas tentang membangun usaha kecil pembuatan kerupuk berbahan susu. Ada beberapa hal positif atau keuntungan jika anda berwirausaha kerupuk susu, antara lain: menjadikan nilai bahan susu pecah yang berkualitas rendah menjadi produk yang ekonomis dan tahan lama; produk olahan susu kerupuk memiliki daya tarik dan nilai gizi yang baik; serta produk ini mudah dalam pemasaran dan menguntungkan

\section{HASIL DAN PEMBAHASAN}

Berdasarkan kegiatan pengabdian masyarakat ini dihasilkan beberapa hal sebagai berikut:

Pelatihan mananjemen usaha kecil. Pelatihan menejemen ini diikuti oleh 10 orang dari dua kelompok usaha krupuk susu. Pelatihan ini berlangsung selama satu hari dengan pemateri berasal dari dosen manajemen dan telah mengembangkan suatu usaha.

Manajemen usaha yang disajikan pada pertemuan ini adalah 1). manajemen terkait strategi perencanaan dan tujuan pembuatan suatu usaha, 2). pengorganisasian sumber daya alam, modal dan fisik untuk mencapai tujuan yang dicanangkan sebelumnya, 3). mengatur hak dan kewajiban bagi anggota (baik dalam hal keuangan maupun administrasi), 4). menumbuhkan rasa kerjasama antara anggota, 5). cara mengontrol seluruh kegiatan yang telah direncanakan, diorganisasikan, diperintahkan, dan dikondisikan sebelumnya agar dapat berjalan sesuai target atau tujuan tertentu.

Hasil dari kegiatan ini, mitra mencoba membuat grand design dari materi yang disampaikan. Grand design ini dikoreksi dan direvisi oleh pemateri. Selanjutnya hasil revisi dicoba untuk diterapkan kedalam proses usaha pembuatan krupuk susu. Pembuatan ijin dagang rumah tangga.

Proses pembuatan ijin dagang rumah tangga terdiri dari beberapa tahapan yaitu: Pertama pendaftaran ke dinkes setempat. Pendaftaran ke dinkes setempat dilakukan dengan membawa produk ke dinkes. Produk akan diamati dan diklasifikasikan apakah perlu dilakukan uji laboratorium. Untuk krupuk susu merupakan olahan dari susu yang bersifat kering, sehingga tidak perlu dilakukan uji laboratorium.

Pada tahap pendaftaran ini, dari dinkes terkait memberikan arahan dan juga menyakan terkait usaha yang dilakukan. Selanjutnya jika telah sesuai dengan standar, mitra dapat mengikuti kegiatan pelatihan selama 2 hari di dinkes setempat. Kegiatan pelatihan.

Selama pelatihan ini, mitra diberikan materi tentang cara pengelolaan suatu usaha, cara menjaga kebersihan dan kehigienisan produk. Hasil kegiatan pelatihan dilanjutkan dengan kegiatan kunjungan lapang oleh dinkes setempat Kunjungan lapangan. Kunjungan lapang dilakukan seminggu setelah kegiatan pelatihan. Dalam kegiatan ini, petugas dinkes mengawasi proses produksi, kebersihan tempat produksi dan cara mengemas produk. Dari hasil kunjungan lapang, mitra pembuat krupuk susu berhasil mendapatkan nomor ijin PIRT dengan nomor 2063507012227. Produksi krupuk susu dijual dalam bentuk mentah dan matang. 


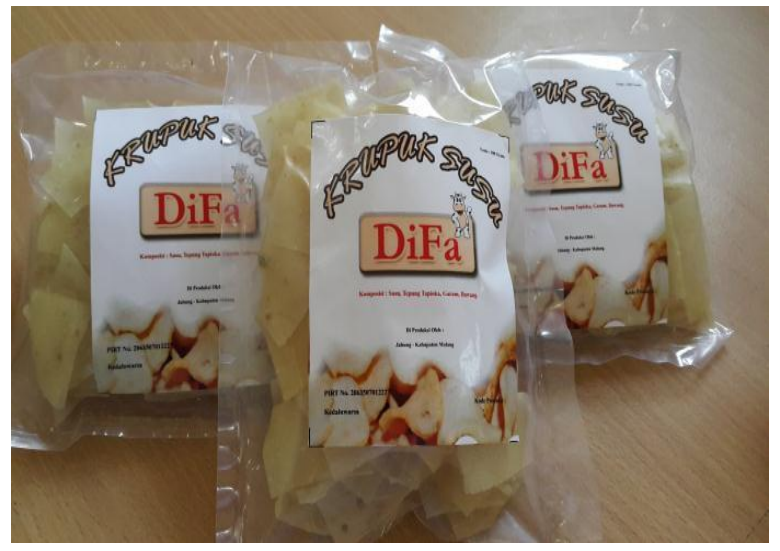

Gambar 1. Krupuk susu mentah

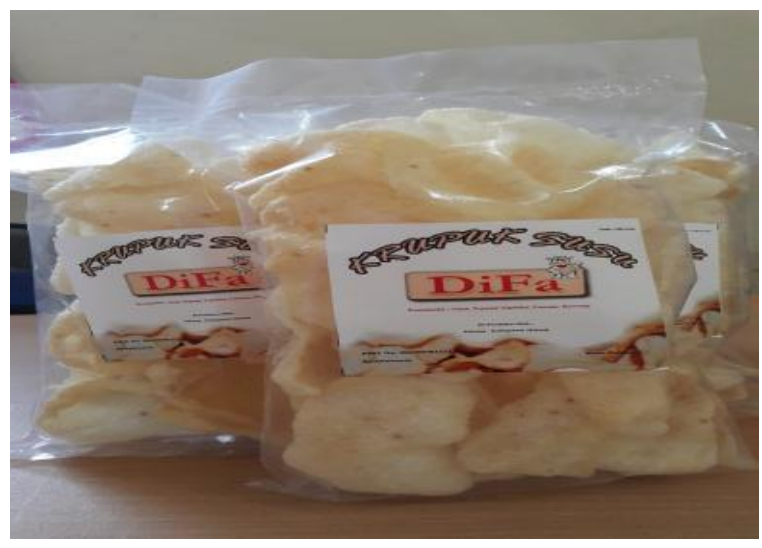

Gambar 2. Krupuk susu matang

Dengan keluarnya nomor PIRT ini membuat mitra menjadi semangat untuk menjual produk krupuk susu ke area yang lebih luas. Beberapa tawaran telah datang berasal dari Toko oleh - oleh Predator Park Batu, Toko daerah Donomulyo, Karangploso dan Kepanjen. Berdasarkan penawaran tersebut, mitra secara bertahap menjual produk krupuk susu tersebut ke Perdator park dan Karangploso dan melayani jual beli online.

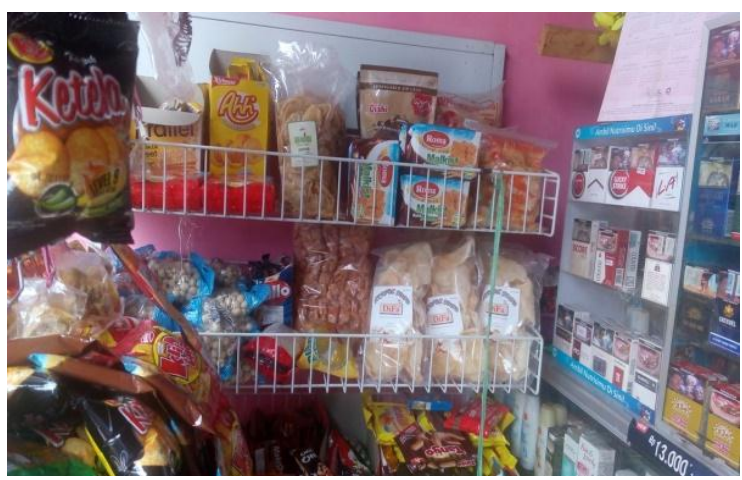

Gambar 3. Gerai krupuk susu a. Kegiatan evaluasi program

Kegiatan evaluasi dilaksanakan oleh pengabdi ketempat mitra untuk mengetahui efektifitas program. Hasil evaluasi yang telah dilakukan diketahui bahwa mitra telah mengembangkan manjemen berbasis usaha kecil dan secara bertahap memenuhi permintaan dari beberapa distributor krupuk susu di berbagai daerah di Kabupaten Malang dan sekitarnya.

\section{KESIMPULAN DAN SARAN}

Kesimpulan dari kegiatan pengabdian yang telah dilakukan adalah mitra te lah mampu mengembangkan manajemen usaha kecil krupuk susu dengan memiliki ijin dagang PIRT sehingga pemasaran yang dilakukan oleh mitra telah sampai pada area yang lebih luas.

\section{DAFTAR PUSTAKA}

Fayol, Henry. 1985. Industri dan Manajemen Umum, Terj. Winardi, London: Sir Issac and Son

Ricky W Griffin. 2004. "Manajemen" : Jakarta,Erlangga 